\title{
Karakteristik Fisik, Kimia, dan Fungsional Pati Ubi Banggai Asetat pada Berbagai Variasi Waktu Reaksi
}

\author{
Physical, Chemical and Functional Characteristics of Banggai Acetate Yam Starch at Various Reaction Times \\ I. If'all1.2, Asirani Hasanuddin ${ }^{3}$, Abdul Rahim $^{4 *}$, Syahraeni Kadir ${ }^{4}$ \\ ${ }^{1}$ Program Doktoral Ilmu Pertanian, Universitas Tadulako Palu, Sulawesi Tengah, Indonesia \\ Jl. Soekarno Hatta Km. 9 Palu, Sulawesi Tengah, 94118 Indonesia \\ ${ }^{2}$ Program Studi Teknologi Hasil Pertanian, Universitas Alkhairaat, Palu, Sulawesi Tengah, Indonesia \\ Jl. Diponegoro No. 39 Palu, Sulawesi Tengah 94221 Indonesia \\ 3Program Studi Peternakan, Universitas Tadulako, Palu, Sulawesi Tengah, Indonesia \\ Jl. Soekarno Hatta Km. 9 Palu, Sulawesi Tengah, 94118 Indonesia \\ 4Program Studi Agroteknologi, Universitas Tadulako, Palu, Sulawesi Tengah, Indonesia \\ Jl. Soekarno Hatta Km. 9 Palu, Sulawesi Tengah, 94118 Indonesia \\ *Penulis korespondensi: Abdul Rahim, E-mail: a_pahira@yahoo.com
}

Tanggal submisi: 24 Agustus 2019; Tanggal penerimaan: 16 April 2020

\begin{abstract}
ABSTRAK
Tanaman ubi Banggai (endemik di Kabupaten Banggai Kepulauan) sangat potensial sebagai bahan baku untuk produksi pati termodifikasi. Salah satu cara untuk meningkatkan nilai tambah pati adalah melakukan modifikasi pati dengan metode asetilasi. Penelitian ini bertujuan untuk menentukan karakteristik fisik, kimia dan fungsional pati ubi Banggai asetat pada berbagai variasi waktu reaksi. Penelitian menggunakan Rancangan Acak Lengkap dengan perlakuan waktu reaksi (T) yaitu T1 : 30 menit, T2 : 35 menit, T3 : 40 menit, T4 : 45 menit, T5 : 50 menit, T6 : 55 menit. Penelitian ini dilakukan untuk menentukan karakteristik pati ubi banggai asetat, yang meliputi persen asetil, derajat substitusi, water dan oil holding capacity (WHC/OHC), daya mengembang, kelarutan, kadar air, abu, lemak, protein, pati dan amilosa pati ubi banggai asetat. Hasil penelitian diperoleh bahwa semakin lama waktu reaksi pada kondisi tertentu akan meningkatkan persen asetil, derajat subtitusi, WHC, OHC, daya mengembang, kelarutan namun menurunkan kadar lemak, air, abu, lemak, protein, pati dan amilosa pati ubi banggai asetat. Pada penelitian ini waktu reaksi terbaik yaitu 50 menit, diperoleh nilai persen asetil 8,658 dan derajat substitusi sebesar 0,356; WHC 32,21\%; OHC 30,21\% daya mengembangan 1,98 g/g dan kelarutan 19,17\%.
\end{abstract}

Katakunci: Asetilasi; pati ubi Banggai asetat; derajat subtitusi; waktu reaksi

\begin{abstract}
Banggai yam plant (endemic in Banggai Kepulauan Regency) is a potential raw material in production of modified starch. The one of techniques to increase the value of starch is modification of starch by acetylation method. This study objectives to determine the physical, chemical and functional characteristics of Banggai acetate yam starch at various reaction times. The study used a Completely Randomized Design with treatment time reaction (T), namely T1: $30 \mathrm{~min}, \mathrm{T2}: 35 \mathrm{~min}, \mathrm{T3}: 40 \mathrm{~min}, \mathrm{T4}: 45 \mathrm{~min}, \mathrm{~T}$ : $50 \mathrm{~min}, \mathrm{~T} 6: 55 \mathrm{~min}$. This study was conducted to determine the characteristics of yam acetate starch, which includes percent acetyl, degree of substitution, water and oil holding capacity (WHC/OHC), flammability, solubility, moisture content, ash, fat, protein, starch and amylose starch. The results showed that the longer reaction time under certain conditions will increase the acetyl percent, degree of substitution, WHC, OHC, flareability, solubility but reduce levels of fat, water, ash, fat,
\end{abstract}

DOI: http://doi.org/10.22146/agritech.48983

ISSN 0216-0455 (Print), ISSN 2527-3825 (Online) 
protein, starch and amylose starch, yam acetate. In this study at the best reaction time is (50 min), gives the acetyl percent $8.658 \%$ and substitution degree of 0.356 , the value of $\mathrm{WHC}, \mathrm{OHC}$, Swelling ratio and solubility of $32.21 \%, 30.21 \%, 1.98 \mathrm{~g} / \mathrm{g}$, and $19.17 \%$ respectively.

Keywords: Acetylation; banggai acetate yam starch; degree of substitution; reaction time

\section{PENDAHULUAN}

Tanaman ubi Banggai (Discorea alata L. dan selanjutnya disebut $D$. alata L.) merupakan tanaman endemik di Kabupaten Banggai Kepulauan dan berpotensi sebagai sumber kalori karena memiliki kandungan $73,1 \%$ karbohidrat, $1,85 \%$ gula, $17,2 \%$ amilum, 3,3\% mineral, 0,3\% lemak, dan 11,95\% protein (Lebot dkk., 2006). Karbohidrat ubi (D. alata L.) termasuk pati berkadar amilosa tinggi dengan rentang 26,98-31,02\% (Jayakody dkk., 2007), memilikipasta yang stabil pada suhu tinggi dan $\mathrm{pH}$ rendah (Mali dkk., 2006), bersifat hipoglikemik (Chen dan Lin, 2007). Hasil penelitian (Sari dkk., 2015) menunjukkan bahwa umbi $D$. alata L. mempunyai indeks glikemik (IG) 22,4 yang rendah sehingga dapat digunakan sebagai bahan pangan pengganti tepung terigu bebas gluten yang aman dikonsumsi bagi penderita diabetes dan autis. Selain itu ubi $D$. alata $\mathrm{L}$ juga memiliki kandungan nutrisi dan senyawa fungsional seperti mucin, dioscin, allantoin, cholinedan asam amino esensial, antosianin (Fang dkk., 2011).

Dalam bidang pangan, ubi Banggai (D. alata L.) telah dimanfaatkan sebagai ubi tumbuk dan amala (Baah dkk., 2009), pati ubi sebagai kertas edible (Mali dkk., 2006), tepung ubi dapat digunakan sebagai bahan penyusun dalam pembuatan mie asin untuk menggantikan sebagian penggunaan tepung gandum (Li dkk., 2012). Umbi D. alata $L$ segar tidak dapat disimpan dalam jangka waktu yang lama sehingga harus diolah menjadi tepung (Jimoh dkk., 2009). Salah satu pemanfaatan tepung $D$. alata $\mathrm{L}$ dapat dijadikanrice paper (kulit lumpia) untuk mempertahankan sifat menguntunkan dari ubi tersebut (Chayapham dkk., 2008).

Modifikasi pati perlu dilakukan untuk meningkatkan nilai tambah pati ubi banggai dalam mempertahankan sifat-sifat yang cocok dalam aplikasi tertentu (Palguna dkk., 2014). Menurut (Kaur dkk., 2012) mengklasifikasikan teknik modifikasi pati menjadi 4 kelompok yaitu modifikasi kimia, fisik, enzimatik, dan bioteknologi. Salah satu modifikasi kimia pati adalah dengan cara esterifikasi. Esterifikasi merupakan cara yang banyak digunakan untuk memodifikasi pati. Menurut Vilpoux dan Averous, (2006), modifikasi pati secara esterifikasi diharapkan dapat meningkatkan karakteristik pati, seperti sifat hidrofobik dan kristalinitas. Penelitian tentang esterifikasi pati sudah sering dilakukan namun penelitian tentang modifikasi dengan esterifikasi pati ubi Banggai yang menggunakan asetat anhidrida hingga saat ini belum banyak dilaksanakan.

Salah satu proses esterifikasi yaitu proses asetilasi. Proses asetilasi ditujukan untuk mendapatkan pati asetat. Faktor yang mempengaruhi laju reaksi kimia adalah termasuk asetilasi pati (Clark, 2002; Xu dkk., 2004), antara lain konsentrasi reagen, derajat keasaman, waktu reaksi, temperatur dan jenis pati. Pemilihan metode asetilasi bertujuan untuk memperbaiki sifat fisik dan kimia pati uwi Banggai, akan tetapi juga dimaksudkan agar pati ubi Banggai yang dihasilkan tidak terhidrolisis oleh enzim amilolitik di usus halus dan kemudian masuk ke kolon. Menurut Chen dkk. (2004) dalam Rahim dkk. (2016) reaksi asetilasi pada pati alami terjadi pada seluruh daerah amorf dan hanya berlangsung pada lamela bagian luar dari daerah kristalin dalam granula pati. Menurut (Sun dan Sun, 2002), lama waktu reaksi asetilasi berperan penting terhadap sifat pati asetat yang dihasilkan. Faktor tersebut sangat menentukan besarnya derajat asetilasi yang dinyatakan dalam derajaubstitusi (DS). DS merupakan parameter yang menentukan penggunaan pati asetat secara komersial dan menentukan besarnya perubahan sifat fungsional pati asetat dari pati alaminya. Modifikasi pati secara asetilasi bekerja dengan mensubtitusi gugus $\mathrm{OH}$ (hidroksil) dengan gugus asetil, proses asetilasi terjadi pada kondisi alkali (basa). Nilai derajat substitusi (DS) seiring meningkat seiring dengan penambahan konsentrasi anhidrida asam asetat (Nurhaeni dkk., 2018).

Penelitian ini mengkaji lama waktu reaksi asetat anhidrida terhadap persen asetil dan derajat substitusi pati ubi banggai asetat selanjutnya mengkarakterisasi pati tersebut. Penelitian bertujuan untuk mendapatkan karakteristik fisik, kimia, dan fungsional pati ubi banggai asetat pada waktu reaksi yang berbeda.

\section{METODE PENELITIAN}

\section{Bahan}

Pati ubi Banggai diperoleh dari Kabupaten Banggai Kepulauan. Bahan kimia untuk proses asetilasi adalah 
asetat anhidrida, $\mathrm{NaOH} 3 \%, \mathrm{HCl} 0,5 \mathrm{~N}$, etanol $96 \%$, $\mathrm{KOH} 0,5 \mathrm{M}$, indikator phenolphtalein, aquades dan beberapa bahan kimia untuk analisis.

\section{Sintesis Pati ubi Banggai Asetat}

Modifikasi pati ubi Banggai dengan asetat anhidrida dilakukan sesuai metode Chi dkk. (2008) dalam Rahim dkk., (2016). Penelitian ini didesain dengan Rancangan Acak Lengkap (RAL) satu faktor dengan faktor yang dicobakan adalah lama waktu reaksi asetat anhidrida yang terdiri atas 6 level, yaitu 30, 35, 40, 45, 50, dan 55 menit. Penelitian diulang 3 kali sehingga terdapat $6 \times 3=18$ unit perlakuan. Adapun sintesis pati ubi banggai asetat yaitu pati ubi banggai sebanyak 100 g didispersi kedalam $225 \mathrm{~mL}$ aquades diaduk dengan pengaduk magnet selama pada suhu ruang selama satu jam. Selanjutnya ditambahkan asetat anhidrida $5 \%$ (v/b) secara tetes demi tetes sambil mempertahankan pH suspensi 8 dengan menambahkan $\mathrm{NaOH} 3 \%$ yang dilakukan pada suhu ruang dengan lama waktu sesuai perlakuan. Setelah itu ditambahkan $\mathrm{HCl}$ 0,5 N sampai $\mathrm{pH}$ 4,5 untuk menghentikan reaksi. Proses selanjutnya adalah pengendapan dan pencucian dengan aquades tiga kali dan etanol satu kali, kemudian pengeringan menggunakan oven dengan suhu $50^{\circ} \mathrm{C}$ selama 20 jam.

\section{Prosedur Analisis}

Persen asetil ditentukan dengan menggunakan metode titrasi (Singh dkk., 2004). Pati ubi banggai asetat sebanyak $1 \mathrm{~g}$ dimasukan ke dalam Erlenmeyer ukuran $250 \mathrm{~mL}$ selanjutnya ditambahkan etanol 75\% sebanyak $50 \mathrm{~mL}$. Dispersi pati kemudian dipanaskan dan di agitasi kedalam waterbath selama 30 menit pada suhu $50^{\circ} \mathrm{C}$ dan kemudian didinginkan pada suhu kamar. Setelah dingin, ditambahkan $40 \mathrm{~mL}$ larutan 0,5 KOH ke dalam suspensi pati selanjutnya diaduk dengan shaker selama 30 menit pada suhu kamar. Setelah pengadukan, kelebihan alkali dititrasi oleh larutan $0,5 \mathrm{M} \mathrm{HCl}$ dan phenolphtalein sebagai indikator sampai warna merah muda menghilang. Sebagai blanko digunakan pati ubi banggai alami. Dengan: W
= berat subtituen yang terikat dengan menggantikan gugus hidrogen pada gugus $\mathrm{OH}$ ( $\%$ berat),
M
= berat molekul substituen (gugus asetil $=0,043$ ),
$\mathrm{W} / \mathrm{M} \quad$ = jumlah mol substituent,
$1 \times \mathrm{W} / \mathrm{M} \quad=$ berat hidrogen $(\%)$,
$162=$ berat molekul satuan glukosa (anhidro, $\mathrm{C}_{6} \mathrm{H}_{10} \mathrm{O}_{5}$ dan
$(100-\mathrm{W} \times \mathrm{W} / \mathrm{M}) / 162$ = berat satuan glukosa

$\%$ asetil $(\mathrm{W})=\frac{[(\text { Blanko-Sampel }) \mathrm{mL} \times \mathrm{M} \mathrm{HCI} \times 0,043 \times 100]}{\text { Berat kering sampel }(\mathrm{g})}$

$\mathrm{HCl}$ yang digunakan untuk titrasi blanko dan sampel dalam $\mathrm{ml} \mathrm{HCl}$, sedangkan sampel dalam berat kering (g). Untuk menghitung DS digunakan Persamaan 2.

$\mathrm{DS}=\frac{162 \mathrm{~W}}{100 \mathrm{M}-(\mathrm{M}-1) \mathrm{W}}$

Selain itu, analisis kadar pati, kadar air, kadar amilosa, kadar protein, kadar lemak, dan kadar abu mengunakan metode (AOAC, 1990). Analisis wateroil holding capacity (WHC-OHC) pati ubi banggai asetat diukur menggunakan metode (Larrauri dkk., 1996). Sebanyak $25 \mathrm{~mL}$ aquades atau minyak zaitun ditambahkan ke $250 \mathrm{mg}$ sampel kering, diaduk lalu dibiarkan selama 1 jampada kondisi suhu kamar. Setelah itu, disentrifugasi residu yang dihasilkan kemudian ditimbang, WHC dan OHC dihitung sebagai g air atau minyak per g sampel kering.

Lebih lanjut analisis daya mengembang (swelling power) dan kelarutan ditentukan dengan metode (Adebowale dkk., 2009). Sampel pati ditambahkan dengan aquades $(1 \%, \mathrm{~b} / \mathrm{v})$ ke dalam tabung reaksi yang telah diukur beratnya $\left(\mathrm{W}_{1}\right)$. Kemudian dipanaskan dengan penangas air pada suhu $80{ }^{\circ} \mathrm{C}$ selama 30 menit, lalu didinginkan. Selanjutnya disentrifugasi dengan kecepatan $3400 \mathrm{rpm}$ selama 15 menit. Residu dan supernatan yang terpisah dan tertahan setelah disentrifugasi kemudian ditimbang $\left(W_{2}\right)$. Daya mengembang pati (berdasarkan berat kering) ditentukan pada Persamaan 3.

Daya mengembang $\left(\frac{\mathrm{g}}{\mathrm{g}}\right)=\frac{W 2-W 1}{\text { berat sampel }}$

Supernatan $(5 \mathrm{~mL})$ dikeringkan hingga berat konstan pada suhu $110^{\circ} \mathrm{C}$. Supernatant dari residu yag dihasilkan kemudian dikeringkan, menunjukkan jumlah pati yang terlarut (\%).

\section{HASIL DAN PEMBAHASAN}

\section{Persen Asetil dan Derajat Substitusi}

Hasil analisis sidik ragam menunjukkan bahwa waktu reaksi berpengaruh nyata terhadap persen asetil dan derajat substitusi pati ubi banggai asetat. Hasil uji lanjut Beda Nyata Jujur (BNJ) $(\alpha$ 0,05) menunjukkan bahwa waktu reaksi 50 menit menghasilkan persen asetil dan derajat substitusi tertinggi $(8,65 \% \mathrm{~A}$; DS $0,356)$ berbeda nyata pada waktu reaksi 30 dan 35 menit namun tidak berbeda nyata pada waktu reaksi 40 dan 55 menit terhadap persen asetil dan derajat substitusi pati ubi banggai asetat tersaji pada Gambar 1. 


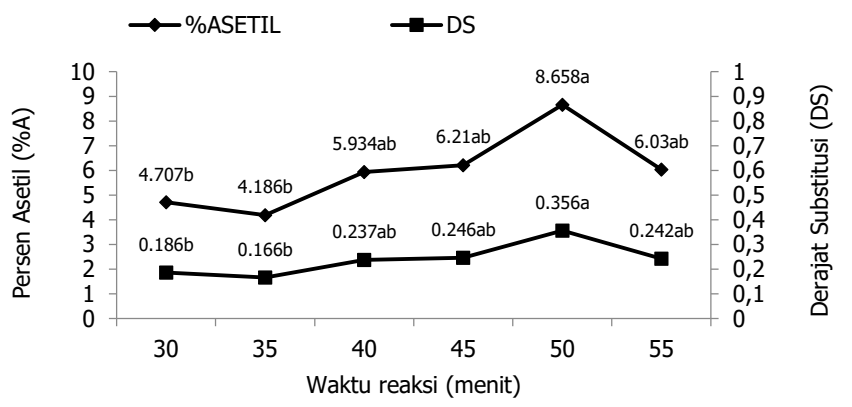

Gambar 1. Rata-rata persen asetil dan derajat subtitusi pati ubi banggai asetat pada berbagai waktu reaksi. Huruf yang berbeda untuk setiap lama waktu reaksi menunjukkan berbeda nyata $(p<0,05 ;$ BNJ $\alpha$ 0,05 : 3,23 (\%A) 0,13 (DS))

Persen asetil pati asetat dan DS meningkat seiring meningkatnya lama waktu reaksi dari 30 menit sampai 50 menit kemudian menurun pada waktu 55 menit. Sejalan dengan penelitian (Rahim dkk., 2012)bahwa peningkatan waktu reaksi dari 10 sampai 40 menit dapat meningkatkan DS, tetapi pada waktu reaksi yang lebih lama (50 sampai 60 menit) menurunkan DS. Hal ini sejalan(Amalia dan Kumoro, 2015) dimanaderajat substitusi (DS) meningkat seriring dengan semakin lama waktu reaksi sampai waktu tertentu (10 sampai 50 menit) kemudian menurun pada waktu reaksi 60 menit. Pola peningkatan persen asetil dan DS tidak bersifat linear, akan tetapi bersifat kuadratik. Persen asetil dan DS meningkat mulai dari waktu reaksi 30 sampai 50 menit yang disebabkan oleh frekuensi terjadinya tumbukan partikel antara pati dengan asetat anhidrida meningkat yang dapat meningkatkan kecepatan reaksi esterifikasi. Menurut Sánchez-Rivera dkk. (2013), penambahan konsentrasi reaktan asetilasi akan meningkatkan derajat subtitusi dan akan memperbesar interaksi antara reaktan dengan pati sehingga mempengaruhi kecepatan reaksi asetilasi. Pada penelitian (Winarti, 2014) juga menyatakan bahwa proses asetilasi 60 menit dapat meningkatkan derajat substitusi dari proses asetilasi 30 menit. Sedangkan Menurut Clark (2002), berdasarkan teori tumbukan, kecepatan reaksi meningkat dapat diakibatkan apabila frekuensi terjadinya benturan antara partikel meningkat. Setelah mencapai optimum maka DS cenderung mengalami penurunan pada waktu reaksi 55 menit yang disebabkan terjadinya reaksi hidrolisis pada pati ubi banggai asetat oleh $\mathrm{NaOH}$ yang menghasilkan pati ubi banggai dengan hasil samping natrium asetat. Hasil penelitian menunjukkan bahwa lama waktu reaksi yang terbaik adalah 50 menit karena telah terjadinya difusi dan absorbs gugus asetil ke dalam molekul pati secara maksimal sehingga menghasilkan nilai DS tertinggi yaitu 0,356. Menurut Sun dan Sun (2002) pada waktu reaksi yang lebih lama, asetat anhidrida mampu mengembangkan granula pati, menyebabkan daerah yang reaktif terhadap bahan kimia menjadi mudah untuk dicapai sehingga meningkatkan laju reaksi. Xu, dkk. (2005) semakin banyak gugus asetil yang masuk ke dalam molekul pati maka akan semakin besar nilai derajat substitusi. Peningkatan hidrasi dan pembengkakan granula pati diakibatkan karena adanya peningkatan akses air ke daerah amorf pati yang disebabkan penggabungan gugus asetil ke dalam molekul pati dapat mengurangi interaksi diantara molekul pati.

Peningkatan derajat substitusi (DS) seriring dengan semakin lama waktu reaksi pula pada waktu tertentu (30 sampai 50 menit) kemudian menurun pada waktu reaksi 55 menit. Peningkatan waktu reaksi dapat menyebabkan semakin banyaknya gugus asetil berdifusi dan teradsorpsi pada permukaan pati (Khalil dkk., 1995). Pola Peningkatan DS pati ubi banggai asetat pada tidak bersifat linier. Reaksiasetilasi berlangsung cepat di waktu awalkemudian menurun setelah waktu reaksi 50 menit. Peningkatan waktu reaksi menyebabkan menurunnya konsentrasi gugus asetil pada pati asetat, selain itu juga disebabkan oleh hidrolisis pati ester (pati asetat) atau air (produk samping esterifikasi dan dari pati) yang tersisa dari reaktor selama proses esterifikasi dapat menghasilkan reaksi eliminasi (Luo dan Zhou, 2012).

Menurut Damat dkk. (2016) bahwa besarnya DS pati butirat mempengaruhi karakteristik fisik dan kimia selain itu dapat meningkatkan kejernihan pasta dan daya mengembang (swelling power).

\section{Kadar Air, Pati, Amilosa, Protein, Lemak, dan Abu}

Hasil analisis sidik ragam menunjukkan waktu reaksi berpengaruh nyata terhadap kadar amilosa, air, lemak dan abu pati ubi banggai asetat, namun tidak berpengaruh nyata terhadap kadar pati dan protein pati ubi banggai asetat. Sebagaimana tersaji pada Tabel 1.

Hasil penelitian menunjukkan bahwa waktu reaksi 30 menit berbeda nyata dengan waktu reaksi 50 dam 55 menit namun tidak berbeda nyata dengan waktu reaksi 35, 40, dan 45 menit terhadap kadar air pati ubi banggai asetat. Kadar air pada pati memiliki pengaruh terhadap daya simpan dari bahan. Semakin tinggi kadar air maka semakin besar pula tingkat kerusakan bahan serta umur simpan dari bahan semakin rendah.

Hasil penelitian menunjukkan bahwa semakin lama waktu reaksi menghasilkan kadar air semakin kecil, Temuan ini sejalan dengan penelitian Heriawan dkk. (2017)yangmenunjukkan bahwa kadar air pati asetat terendah dicapai pada lama reaksi 60 menit berkisar $6,69 \%$ dan kadar air tertinggi pada lama reaksi 15 menit berkisar 9,30\%. Rendahnya kadar air pati 
Tabel 1. Komposisi kimia pati ubi banggai dan pati ubi banggai asetat pada berbagai waktu reaksi (\%bk)

\begin{tabular}{|c|c|c|c|c|c|c|c|c|}
\hline \multirow{2}{*}{$\begin{array}{l}\text { Komposisi kimia } \\
\text { (\%bk) }\end{array}$} & \multirow{2}{*}{$\begin{array}{l}\text { Pati ubi banggai } \\
\text { alami }\end{array}$} & \multicolumn{6}{|c|}{$\begin{array}{c}\text { Modifikasi pati ubi banggai asetat pada berbagai waktu } \\
\text { reaksi (menit) }\end{array}$} & \multirow[t]{2}{*}{ BNJ $a=0,05$} \\
\hline & & 30 & 35 & 40 & 45 & 50 & 55 & \\
\hline Kadar air & 11,88 & $12,28^{a}$ & $12,30^{\mathrm{a}}$ & $12,25^{\mathrm{ab}}$ & $12,23^{\mathrm{ab}}$ & $12,19^{b}$ & $12,19^{b}$ & 0,08 \\
\hline Kadar abu & 1,33 & $1,01^{\mathrm{b}}$ & $1,17^{\mathrm{ab}}$ & $1,10^{\mathrm{b}}$ & $1,22^{\mathrm{a}}$ & $0,78^{c}$ & $0,76^{c}$ & 0,11 \\
\hline Kadar protein & 7,61 & $7,19^{a}$ & $7,27^{a}$ & $6,96^{a}$ & $6,12^{\mathrm{a}}$ & $7,47^{a}$ & $7,44^{a}$ & tn \\
\hline Kadar lemak & 1,39 & $1,24^{\mathrm{a}}$ & $1,20^{\mathrm{ab}}$ & $1,14^{\mathrm{ab}}$ & $1,13^{\mathrm{b}}$ & $0,82^{c}$ & $0,65^{d}$ & 0,09 \\
\hline Kadar pati & 83,48 & $56,50^{\text {a }}$ & $78,80^{\mathrm{a}}$ & $75,92^{\mathrm{a}}$ & $77,42^{\mathrm{a}}$ & $74,89^{a}$ & $73,94^{a}$ & tn \\
\hline Kadar amilosa & 25,80 & $24,70^{\mathrm{ab}}$ & $25,16^{a}$ & $25,09^{a}$ & $23,01^{\mathrm{b}}$ & $22,29 \mathrm{bc}$ & $21,45^{c}$ & 1,16 \\
\hline
\end{tabular}

Keterangan: Huruf yang berbeda untuk setiap lama waktu reaksi menunjukkan berbeda nyata $(p<0,05)$

asetat setelah mengalami modifikasi dengan asetilasi menyebabkan gugus hidroksil pada pati tergantikan oleh gugus asetil yang bersifat lebih nonpolar sehingga produk asetilasinya menjadi kurang higroskopis karena kemampuan menjerap air dari gugus ester pada pati asetat tidak sebaik gugus alkohol pada pati. Secara umum, kadar air produk asetilasi sesuai dengan nilai derajat substitusinya. Semakin besar derajat substitusi maka kadar airnya semakin kecil.

Hasil penelitian menunjukkan bahwa kadar pati yang tertinggi diperoleh pada waktu reaksi 35 menit dan kadar pati terendah diperoleh pada waktu reaksi 30 menit. Kadar pati menunjukkan tingkat kemurnian pati hasil ekstraksi. Pati merupakan bentuk polisakarida yang tersimpan dalam jaringan tanaman, yang berupa granula dalam kloroplas daun dan amiloplas biji dan umbi (Sajilata dkk., 2006). Hasil penelitian menunjukkan bahwa terjadi peningkatan kadar pati ubi banggai asetat pada lama waktu reaksi 35 menit kemudian terjadi penurunan kadar pati ubi banggai asetat hingga pada lama waktu reaksi 55 menit, hal ini diduga oleh adanya depolimerisasi pati selama proses asetilasi. Terjadinya depolimerisasi tersebut diduga karena pati mengalami hidrolisis oleh air yang terdapat dalam pati ubi banggai dengan bantuan asetat anhidrida. Sun dan Sun (2002), menyatakan bahwa penggunaan katalis asam mineral kuat dalam proses asetilasi dapat menyebabkan hidrolisis rantai polimer karbohidrat. Selain itu, semakin lama waktu reaksi, kemungkinan terjadinya depolimerisasi pati menjadi molekul-molekul yang lebih kecil semakin besar, akibatnya semakin kecil molekul peluang terjadinya reaksi asetilasi semakin besar.

Hasil uji lanjut BNJ $(\alpha 0,05)$ menunjukkan bahwa waktu reaksi 35 menit berbeda nyata dengan waktu reaksi 45, 50, dan 55 menit namun tidak berbeda nyata dengan waktu reaksi 30 dan 40 menit terhadap kadar amilosa pati ubi banggai asetat. Pati tersusun atas komponen amilosa dan amilopektin. Kandungan amilosa diukur berdasarkan kemampuan amilosa untuk luruh dalam air panas dan kemampuan dalam mengikat iod. Karaktersitik produk sangat dipengaruhi oleh kandungan amilosa. Retrogradasi produk pati semakin muda terjadi jika kandungan amilosa semakin tinggi. Kadar amilosa pati ubi banggai asetat pada berbagai lawa waktu reaksi berkisar antara $21,45 \%$ sampai dengan $25,16 \%$.

Hasil penelitian (BNJ $\alpha 0,05)$ bahwa waktu reaksi 35 menit berbeda nyata dengan waktu reaksi 45, 50 dan 55 menit, namun tidak berbeda nyata dengan waktu reaksi 30 dan 40 menit terhadap kadar lemak pati ubi banggai asetat. Dalam penelitian ini, kadar protein dalam pati berkisar antara 6,12- 7,40\% (\%bk). Kandungan lemak dan protein dalam pati yang tinggi namun keberadaannya kurang diharapkan karena menyebabkan penurunan kadar pati resisten. Hal ini sesuai pernyataan Sajilata dkk. (2006) bahwa pembentukan pati resisten dipengaruhi oleh beberapa komponen pangan antara lain: protein, lipid, serat pangan, enzim inhibitor dan ion. Namun kandungan kimia tidak terlihat perbedaan yang signifikan antara pati ubi banggai alami dan pati ubi banggai yang telah dimodifikasi.

Hasil penelitian menunjukkan bahwa waktu reaksi 45 menit tidak berbeda nyata dengan waktu reaksi 35 menit tetap berbeda nyata dengan waktu reaksi 30, 40, 50, dan 55 menit terhadap kadar abu pati ubi banggai asetat. Penetralan $\mathrm{HCl}$ dengan $\mathrm{NaOH}$ akan membentuk garam dalam proses litnerisasi menyebabk terjadi peningkatan kadar abu. Peningkatan kadar abu juga diakibatkan adanya penambahan asetat anhidrida yang mana masih ada gugus asetil yang belum berikatan menghasilkan residu karena proses asetilasi yang terjadi tidak selalu sempurna. Kadar abu juga mengalami penurunan sesuai dengan peningkatan waktu reaksi asetat anhidrida.

\section{Water dan Oil Holding Capacity (WHC-OHC)}

Hasil analisis sidik ragam menunjukkan bahwa waktu reaksi berpengaruh nyata terhadap water dan oil 
holding capacity pati ubi banggai asetat, tersaji pada Gambar 3.Hasil penelitian menunjukkan (BNJ $\alpha 0,05$ ) bahwa waktu reaksi 50 menit tidak berbeda nyata dengan waktu reaksi 55 meniti tetapi berbeda nyata dengan waktu reaksi 30, 40, dan 45 menit terhadap water holding capacity pati ubi banggai asetat. Hasil penelitian juga menunjukkan bahwa lama waktu reaksi 50 menit berbeda nyata dengan 35 dan 40 menit namun tidak berbeda nyata dengan 30 dan 55 menit terhadap oil holding capacity.

Hasil penelitian menunjukkan bahwa WHC dan $\mathrm{OHC}$ dari pati ubi banggai asetat meningkat dengan meningkatnya DS. Hasil ini menunjukkan bahwa sifat hidrofilik dan hidrofobik lebih baik setelah asetilasi. Peningkatan WHC dan OHC disebabkan oleh perubahan geometric dan gugus fungsional asetat pada molekul pati yang mempunyai kemampuan menahan air dan minyak. Adanya kemampuan menyerap air dan minyak pada pati menunjukkan bahwa pati memiliki bagian yang bersifat hidrofilik dan hidrofobik. Peningkatan sifat hidrofobik dari pati disebabkan oleh jumlah gugus hidroksil(bersifat hidrofil) yang tersubstitusi semakin meningkat (Z.-G. Luo dan Shi, 2012). Daya ikat minyak pada pati dipengaruhi adanya protein dipermukaan granula pati yang dapat membentuk kompleks dapat membuat terikatnya minyak pada pati, juga berhubungan dengan amilosa yang terkandung dalam pati. Amilosa memiliki kemampuan untuk membentuk kompeks dengan minyak dan membentuk amilosa lipid (Rizkiana, 2015).

Proses modifikasi asetilasi akan lebih meningkatkan penyerapan air dan minyak. Menurut Winarti (2014), peningkatan daya serap air dan minyak setelah proses asetilasi berkaitan dengan pembentukan struktur berpori dan ukuran yang lebih halus dari hasil proses presipitasi. Kapasitas pengikatan minyak digunakan untuk mengukur tingkat hidrifobisitas produk. Proses asetilasi dalam

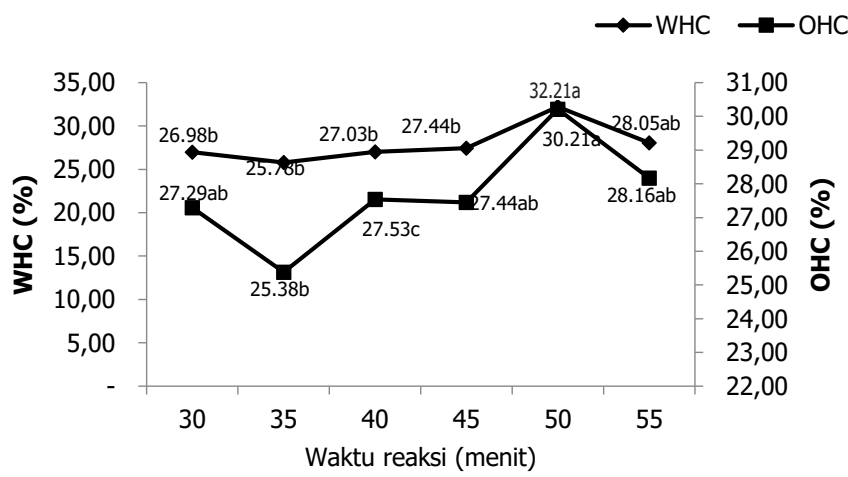

Gambar 2. Rata-rata water dan oil holding capacity (whc/ohc) pati ubi banggai asetat pada berbagai waktu reaksi. Huruf yang berbeda untuk setiap lama waktu reaksi menunjukkan berbeda nyata ( $p<0,05$; BNJ $\alpha$ 0,05: 4,55 (WHC) 3,28 (OHC)). penelitian ini bertujuan untuk memodifikasi pati dan meningkatkan sifat hidrofobisitasnya, sehingga dapat digunakan sebagai matriks untuk proses enkapsulasi zat aktif yang bersifat hidrofobik.

\section{Daya Mengembang dan Kelarutan}

Hasil analisis sidik ragam menunjukkan bahwa waktu reaksi berpengaruh nyata terhadap daya mengembang dan kelarutan pati ubi banggai asetat, tersaji pada gambar 4. Hasil menunjukkan (BNJ $\alpha=$ 0,05 ) bahwa waktu reaksi 50 menit memperoleh daya mengembang tertinggi tidak berbeda nyata dengan waktu reaksi 30, 35, dan 55 menit tetap berbeda nyata dengan waktu reaksi 40 dan 45 menit. Waktu reaksi 50 menit juga memberikan nilai indeks kelarutan tertinggi yangberbeda nyata dengan waktu reaksi 30 dan 35 menit namun tidak berbeda nyata dengan 40, 45, dan 55 menit. Kelarutan dan swelling power (SP) merupakan salah satu sifat fungsional pati. Swelling atau kapasitas menyerap air pada pati sangat penting dalam aplikasi biomedis atau farmasi, baik sebagai implant maupun sebagai penghantaran obat. Peningkatan daya mengembang dan kelarutan disebabkan olehproses hidrolisis yangmemecah rantai pati menjadi lebih pendek danmerusak granula pati dan sehingga pati lebih mudah larut. Peningkatan kelarutan akibat rantai pati lebih pendek yang menandakan bahwa berat molekul yang lebih kecil (Winarti, 2014). Semakin lama waktu reaksi dapat meningkatan daya mengembang dan kelarutan pati asetat (Amalia dan Kumoro, 2015).

Berdasarkan Gambar 3, nilai rata-rata daya mengembang 13,28-19,17 g/g dan kelarutan 1,38$1,98 \%$ yang berpengaruh nyata terhadap waktu reaksi pati ubi banggai asetat. Hal ini menunjukkan bahwa daya mengembang disebabkan adanya substitusi gugus hidroksil disubtitusi oleh gugus asetil sehingga ikatan hidrogen menjadi lemah sehingga struktur granula pati menjadi kurang rapat, hal ini dapat memfasilitasi akses air masuk pada daerah amorf. Peningkatan daya mengembang diakibatkan lemahnya ikatan

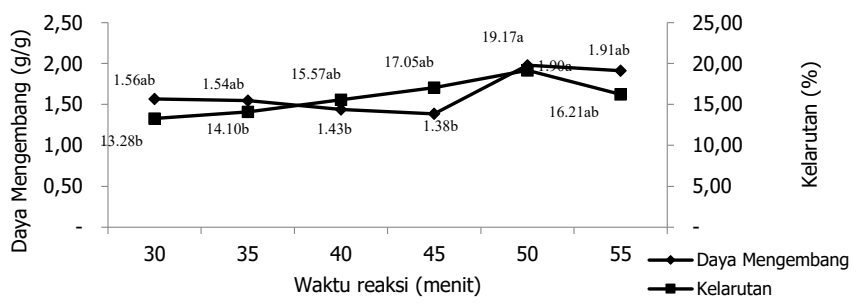

Gambar 3. Rata-rata daya mengembang dan kelarutan pati ubi banggai asetat pada berbagai waktu reaksi. Huruf yang berbeda untuk setiap lama waktu reaksi menunjukkan berbeda nyata ( $p<0,05$; BNJ $\alpha$ 0,05:0,49 (Daya Mengembang); 4,48 (Kelarutan)). 
hidrogen pada molekul pati yang dimodifikasi sehingga memudahkan air lebih mudah masuk ke dalam granula pati. Semakin banyak gugus yang tersubtitusi, ikatan hidrogen semakin lemah, sehingga struktur kristalin menghilang menjadi amor (Adebowale dkk., 2009; Xu dkk., 2005).Peningkatan kelarutan diakibatkan karena melemahnya ikatan hidrogen pada molekul pati sehingga air lebih mudah masuk ke dalam granula pati sehingga amilosa keluar dari granula pati Karene adanya subtitusi gugus asetil pada pati ubi banggai. Namun setelah waktu reaksi 50 menit nilai kelarutanmenjadi menurun. Hal ini pengaruhioleh jumlah gugus hidroksil (bersifat hidrofil) yang tersubstitusi meningkat menyebabkan peningkatan sifat hidrofobik pati sehingga mengurangi tingkat kelarutan pati di dalam air (Z. Luo dan Zhou, 2012).

Dari hasil penelitian daya mengembang mengalami peningkatan pada setiap proses, hal ini sesuai dengan pernyataan (Damat dkk., 2016) bahwa peningkatan daya mengembang disebabkan karena melemahnya ikatan hidrogen pada molekul pati sehingga granula pati mudah menyerap air. Melemahnya ikatan hidrogen karena terjadinya reaksi sterik dimana molekul amilosa tidak bebas untuk saling bergabung atau berikatan karena adanya gugus asetil yang terikat pada molekul pati.

Peningkatan waktu reaksi dapat meningkatan nilai DS pati, Peningkatan DS menyebabkan daya mengembang dan kelarutan pati ubi banggai asetat semakin meningkat. Amalia dan Kumoro, (2016), peningkatan daya mengembang dan kelarutan disebabkan adanya substitusi gugus asetil menjadi gugus hidroksil yang dapat melemahkan ikatan hidrogen antara molekul pati. Semakin lama waktu reaksi maka semakin banyak gugus asetil berdifusi dan teradsorpsi pada permukaan pati.

\section{KESIMPULAN}

Persentase asetil dan derajat substitusi maksimum diperoleh pada waktu reaksi asetat anhidrida 50 menit, sebesar 5,658\% dan0,356. Karakteristik fisik, kimia dan fungsional pati ubi banggai asetat dipengaruhi oleh besarnya DS. Pati asetat DS yang tinggi memiliki daya ikat air, daya ikat minyak, daya mengembang (swelling power) dan kelarutanyang lebih tinggi dengan nilai masing-masing $32,21 \%, 30,21 \%, 1,98 \mathrm{~g} / \mathrm{g}$,dan $19,17 \%$.

\section{UCAPAN TERIMA KASIH}

Ucapan terimakasih kami sampaikan kepada Kementerian Riset, Teknologi dan Pendidikan Tinggi yang telah mendukung pendanaan melalui skema Penelitian Dasar dengan Kontrak Nomor: 100/SP2H/LT/ DRPM/2019 Tanggal 21 Maret 2019.

\section{KONFLIK KEPENTINGAN}

Penulis menyatakan tidak ada konflik atau kepentingan dengan pihak lain.

\section{DAFTAR PUSTAKA}

Amalia, R., \& Kumoro, A. C. (2015). Studi pengaruh rasio reaktan, $\mathrm{pH}$, dan waktu reaksi terhadap sifat fisikokimia tepung gadung (Dioscorea hispida Dennst.) Terasetilasi. Metana, 11(02). https://doi.org/10.14710/metana. v11i02.14756

Amalia, R., \& Kumoro, A. C. (2016). Analisis Sifat Fisikokimia Dan Uji Korelasi Regresi Antara Nilai Derajat Substitusi Dengan Swelling Power Dan Solubility Pada Tepung Gadung (Dioscorea hispida Dennst) Terasetilasi. Jurnal Inovasi Teknik Kimia, 1(1). Retrieved from https:// publikasiilmiah.unwahas.ac.id/index.php/inteka/article/ view/1640

AOAC. (1990). Official Methods of Analysis. Method 985.29.15th. Washington D.C, 771.

Baah, F. D., Maziya-Dixon, B., Asiedu, R., Oduro, I., \& Ellis, W. O. (2009). Nutritional and biochemical composition of D. alata (Dioscorea spp.) tubers. Retrieved from http:// ir.knust.edu.gh:8080/handle/123456789/9766

Chayapham, O., Uttapap, D., Puttarnlek, C., \& Rungsardthong, V. (2008). Improvement of rice paper quality by mixing rice flour with canna starch. KMUTT Research and Development Journal, 31(2), 245-260.

Chen, Y.-T., \& Lin, K.-W. (2007). Effects of heating temperature on the total phenolic compound, antioxidative ability and the stability of dioscorin of various yam cultivars. Food Chemistry, 101(3), 955-963. https://doi.org/10.1016/j. foodchem.2006.02.045

Clark, J. (2002). Factors influencing Rate of Reaction. Retrieved from https://www.chemguide.co.uk/physical/ basicrates/arrhenius.html

Damat, D., Haryadi, H., Marsono, Y., \& Cahyanto, M. N. (2016). Efek $\mathrm{pH}$ dan Konsentrasi Butirat Anhidrida selama Butirilisasi Pati Garut. AgriTECH, 28(2). https://doi. org/10.22146/agritech.9864

Fang, Z., Wu, D., Yü, D., Ye, X., Liu, D., \& Chen, J. (2011). Phenolic compounds in Chinese purple yam and changes during vacuum frying. Food Chemistry, 128(4), 943948. https://doi.org/10.1016/j.foodchem.2011.03.123

Heriawan, I. K. A., Rahim, A., \& Kadir, S. (2017). Karakteristik fisikokimia pati aren asetat. Agroland: Jurnal IlmuIlmu Pertanian, 23(2), 157-163. https://doi. org/10.22487/J.24077607.2016.v23.i2.8325 
Jimoh, K. O., Olurin, T. O., \& Aina, J. O. (2009). Effect of drying methods on the rheological characteristics and colour of yam flours. African Journal of Biotechnology, 8(10). Retrieved from https://www.ajol.info/index.php/ajb/ article/view/60584

Kaur, B., Ariffin, F., Bhat, R., \& Karim, A. A. (2012). Progress in starch modification in the last decade. Food Hydrocolloids, 26(2), 398-404. https://doi. org/10.1016/j.foodhyd.2011.02.016

Khalil, M. I., Hashem, A., \& Hebeish, A. (1995). Preparation and Characterization of Starch Acetate. Starch Stärke, 47(10), 394-398. https://doi.org/10.1002/ star. 19950471005

Larrauri, J. A., Rupérez, P., Borroto, B., \& Saura-Calixto, F. (1996). Mango Peels as a New Tropical Fibre: Preparation and Characterization. LWT - Food Science and Technology, 29(8), 729-733. https://doi.org/10.1006/fstl.1996.0113

Lebot, V., Malapa, R., Molisale, T., \& Marchand, J. L. (2006). Physico-chemical characterisation of yam (Dioscorea alata L.) tubers from Vanuatu. Genetic Resources and Crop Evolution, 53(6), 1199-1208. https://doi. org/10.1007/s10722-005-2013-2

Li, P.-H., Huang, C.-C., Yang, M.-Y., \& Wang, C.-C. R. (2012). Textural and sensory properties of salted noodles containing purple yam flour. Food Research International, 47(2), 223-228. https://doi.org/10.1016/j. foodres.2011.06.035

Luo, Z., \& Zhou, Z. (2012). Homogeneous synthesis and characterization of starch acetates in ionic liquid without catalysts. Starch - Stärke, 64(1), 37-44. https://doi. org/10.1002/star.201100073

Luo, Z.-G., \& Shi, Y.-C. (2012). Preparation of Acetylated Waxy, Normal, and High-Amylose Maize Starches with Intermediate Degrees of Substitution in Aqueous Solution and Their Properties. Journal of Agricultural and Food Chemistry, 60(37), 9468-9475. https://doi. org/10.1021/jf301178c

Mali, S., Grossmann, M. V. E., García, M. A., Martino, M. N., \& Zaritzky, N. E. (2006). Effects of controlled storage on thermal, mechanical and barrier properties of plasticized films from different starch sources. Journal of Food Engineering, 75(4), 453-460. https://doi.org/10.1016/j. jfoodeng.2005.04.031

Nurhaeni, N., Dwiasmukti, P., \& Prismawiryanti, P. (2018). Modifikasi Pati Sukun (Artocarpus altilis) Menggunakan Anhidrida Asam Asetat dan Aplikasinya pada Pembuatan Mie Kovalen Jurnal Riset Kimia, 4(1), 33-40. https://doi. org/10.22487/j24775398.2018.v4.i1.10181

Palguna, I. G. P. A., Sugiyono, S., \& Hariyanto, B. (2014). Karakteristik Pati Sagu yang Dimodifikasi dengan Perlakuan Gelatinisasi dan Retrogradasi Berulang Characteristics of Modified Sago (Metroxylon sagu) Starch by Gelatinization and Retrogradation Cycling. Jurnal
Pangan, 23(2), 146-157. https://doi.org/10.33964/ jp.v23i2.59

Rahim, A., Alam, N., Hutomo, G. S., \& Kadir, S. (2016). Teknologi Modifikasi Pati Aren. Yogyakarta: Magnum Pustaka Utama.

Rahim, A., Haryadi, Cahyanto, M. N., \& Pranoto, Y. (2012). Characteristics of butyrylated arenga starch prepared at different reaction time and butyric anhydride concentration. Retrieved from http://agris.upm.edu. my:8080/dspace/handle/0/11852

Rizkiana, W. (2015). Produksi Pati Tapioka Nanokristalin Terasetilasi. Retrieved from http://repository.ipb.ac.id/ handle/123456789/74931

Sajilata, M. G., Singhal, R. S., \& Kulkarni, P. R. (2006). Resistant Starch-A Review. Comprehensive Reviews in Food Science and Food Safety, 5(1), 1-17. https://doi. org/10.1111/j.1541-4337.2006.tb00076.x

Sánchez-Rivera, M. M., Almanza-Benitez, S., Bello-Perez, L. A., Mendez-Montealvo, G., Núñez-Santiago, M. C., Rodriguez-Ambriz, S. L., \& Gutierrez-Meráz, F. (2013). Acetylation of banana (Musa paradisiaca L.) and corn (Zea mays L.) starches using a microwave heating procedure and iodine as catalyst: II. Rheological and structural studies. Carbohydrate Polymers, 92(2), 12561261. https://doi.org/10.1016/j.carbpol.2012.10.040

Sari, I. P., Lukitaningsih, E., Rumiyati, R., \& Setiawan, I. M. (2015). Glycaemic Index Of Uwi, Gadung, And Talas Which Were Given On Rat. Majalah Obat Tradisional, 18(3), 127-131. https://doi.org/10.22146/ tradmedj.8196

Singh, N., Chawla, D., \& Singh, J. (2004). Influence of acetic anhydride on physicochemical, morphological and thermal properties of corn and potato starch. Food Chemistry, 86(4), 601-608. https://doi.org/10.1016/j. foodchem.2003.10.008

Sun, R., \& Sun, X. F. (2002). Structural and thermal characterization of acetylated rice, wheat, rye, and barley straws and poplar wood fibre. Industrial Crops and Products, 16(3), 225-235. https://doi.org/10.1016/ S0926-6690(02)00050-X

Vilpoux, O., \& Averous, L. (2006). Starch-Based Plastic. Latin American Starchy Tubers.

Winarti, C. (2014). Produksi pati garut nano partikel sebagai matriks enkapsulasi bahan bioaktif herbal. IPB, Bogor.

Xu, Y., Miladinov, V., \& Hanna, M. A. (2004). Synthesis and Characterization of Starch Acetates with High Substitution. Cereal Chemistry, 81(6), 735-740. https:// doi.org/10.1094/CCHEM.2004.81.6.735

Xu, Y. X., Dzenis, Y., \& Hanna, M. A. (2005). Water solubility, thermal characteristics and biodegradability of extruded starch acetate foams. Industrial Crops and Products, 21(3), 361-368. https://doi.org/10.1016/j. indcrop.2004.05.004 